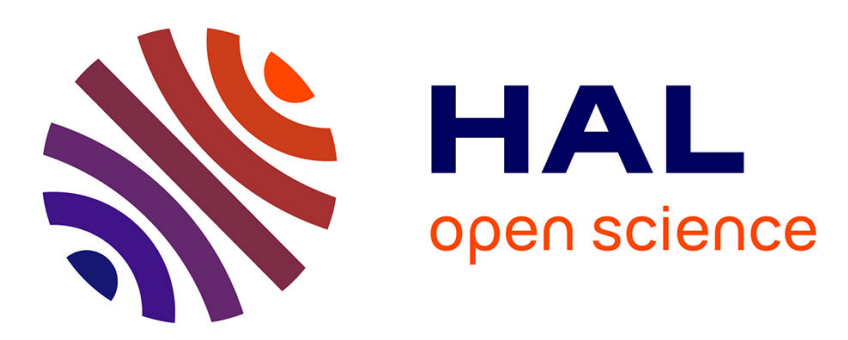

\title{
Effects of a concentrate of pea antinutritional factors on pea protein digestibility in piglets
}

\author{
M.P. Le Guen, J. Huisman, G. Beelen, M.W.A. Verstegen
}

\section{To cite this version:}

M.P. Le Guen, J. Huisman, G. Beelen, M.W.A. Verstegen. Effects of a concentrate of pea antinutritional factors on pea protein digestibility in piglets. Livestock Production Science, 1995, 44, pp.157-167. hal-02709130

\section{HAL Id: hal-02709130 \\ https://hal.inrae.fr/hal-02709130}

Submitted on 1 Jun 2020

HAL is a multi-disciplinary open access archive for the deposit and dissemination of scientific research documents, whether they are published or not. The documents may come from teaching and research institutions in France or abroad, or from public or private research centers.
L'archive ouverte pluridisciplinaire HAL, est destinée au dépôt et à la diffusion de documents scientifiques de niveau recherche, publiés ou non, émanant des établissements d'enseignement et de recherche français ou étrangers, des laboratoires publics ou privés. 


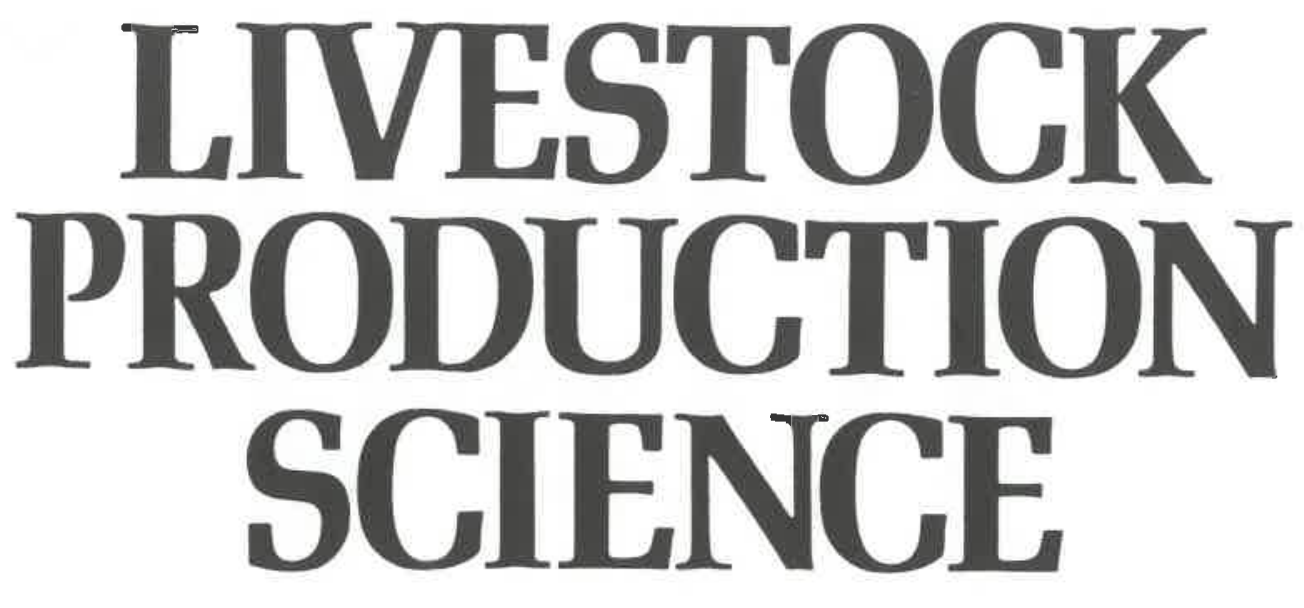

Livestock Production Science 44 (1995) 157-167

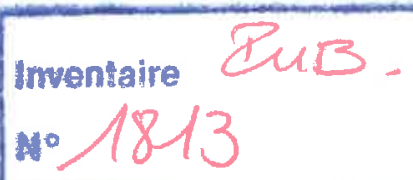

\title{
Effects of a concentrate of pea antinutritional factors on pea protein digestibility in piglets
}

\author{
M.P. Le Guen ${ }^{\mathrm{a}, *}$, J. Huisman ${ }^{\mathrm{b}}$, J. Guéguenc ${ }^{\mathrm{c}}$, G. Beelenc, M.W.A. Verstegen ${ }^{\mathrm{d}}$ \\ "G.I.E. EURETEC II, 85 rue de St Brieuc, 35000 Rennes, France \\ 'ILOB-TNO. Department of Animal Nutrition and Physiology, P.O. Box 15, 6700 AA Wageningen, The Netherlands \\ 'INRA, L.B.T.P.. Rue de Géraudière, B.P. 1627, 44316 Nantes Cedex 03, France \\ 'Department of Animal Nutrition, Agricultural University, Marijkeweg 40, 6709 PG Wageningen. The Netherlands
}

Accepted 23 June 1995

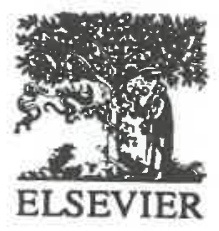




\title{
Effects of a concentrate of pea antinutritional factors on pea protein digestibility in piglets
}

\author{
M.P. Le Guen ${ }^{\mathrm{a}, *}$, J. Huisman ${ }^{\mathrm{b}}$, J. Guéguen ${ }^{\mathrm{c}}$, G. Beelen ${ }^{\mathrm{c}}$, M.W.A. Verstegen ${ }^{\mathrm{d}}$ \\ ${ }^{a}$ G.I.E. EURETEC II, 85 rue de St Brieuc, 35000 Rennes, France \\ "ILOB-TNO, Department of Animal Nutrition and Physiology, P.O. Box 15, 6700 AA Wageningen, The Netherlands \\ 'INRA, L.B.T.P., Rue de Géraudière, B.P. 1627, 44316 Nantes Cedex 03, France \\ ${ }^{d}$ Department of Animal Nutrition, Agricultural University, Marijkeweg 40, 6709 PG Wageningen, The Netherlands
}

Accepted 23 June 1995

\begin{abstract}
Four experiments were designed to investigate the apparent ileal digestibility of raw pea (Pisum sativum) and two of its components - an isolate of its proteins and a concentrate of its proteinaceous antinutritional factors (ANFs). Three varieties of peas were used: spring varieties Finale and Solara, and winter variety Frijaune. Pea protein isolates, devoided of pea carbohydrates and characterized by low trypsin inhibitor activities, were produced from Finale and from Frijaune. Two concentrates of ANFs were used; one from Finale and Frijaune (1:1) (batch a), one from Frijaune (batch b). The trypsin inhibitor activity was three times higher in batch $b$ than in batch a. Eleven semi-synthetic diets containing the pea protein isolate, the pea ANF concentrates or raw peas were fed to piglets ( $10-15 \mathrm{~kg}$ live weight) fitted with post-valvular T-caecum cannula. For the raw pea diets, the apparent ileal $\mathrm{N}$ digestibility coefficients were $69.1 \%$ (Finale) and $69.5 \%$ (Frijaune). For the diets based on pea protein isolate, they were $83.7 \%$ (Finale) and $85.4 \%$ (Frijaune). Incorporation of $2.9 \%$ ANF concentrate (batch a) reduced the N digestibility coefficient of the diet based on Finale pea protein isolate from $83.7 \%$ to $79 \%$. Addition of $0.6 \%$ of the other ANF concentrate (batch b) reduced the $\mathrm{N}$ digestibility coefficient when the diet was based on Solara raw pea ( -3 units) and not when based on pea protein isolate.
\end{abstract}

Keywords: Pig; Pea; Digestibility; Antinutritional factor; Protein

\section{Introduction}

White-flowered peas (Pisum sativum) are considered to be valuable dietary protein source for both animals and humans. Nevertheless, growth performance of piglets have been shown to be depressed when the diets, balanced in essential amino acids, contained $40 \%$ spring peas (Jondreville et al., 1992), or 15, 30 or $45 \%$ spring peas (Bengala Freire et al., 1989). However, in other experiments, incorporation of $30 \%$ spring peas in

\footnotetext{
* Corresponding author
}

piglet diets balanced in amino acids did not affect growth performance (Gatel et al., 1989; Grosjean et al., 1991). Among pea constituents, several may be responsible for the reduced growth performance.

Starch has been sometimes considered as a possible negative factor (Longstaff and McNab, 1987; Bengala Freire et al., 1988) in relation to its low susceptibility to hydrolysis (Colonna and Mercier, 1979; Colonna et al., 1992). The alpha-galactosides, soluble carbohydrates present in peas at a level of about 5\% (Quemener and Mercier, 1980), may also play a negative role 
(Cristofaro et al., 1974; Saini, 1989) as they would not be hydrolysed in the small intestine. However, it was found that addition of isolated pea carbohydrates did not affect the $\mathrm{N}$ apparent ileal digestibility of pea protein isolate (Huisman et al., 1990). Besides these constituents, protease inhibitors (Valdebouze et al., 1980; Griffiths, 1984) and lectins (Meehan et al., 1982) are considered as antinutritional factors (ANFs) for their possible negative effects on protein digestibility (Leterme et al., 1990).

The objective of this study was to understand the effect of proteinaceous ANFs on the digestion of raw white-flowered pea or pea protein isolate in piglets, through digestibility experiments.

\section{Materials and methods}

Four experiments with piglets were carried out to measure the apparent ileal digestibility of diets containing high levels of either raw peas or pea protein isolate, for the spring variety Finale in Expt. 1 and for the winter variety Frijaune in Expt. 2. The influence of adding pea ANF concentrate to Finale pea protein isolate diet on digestibility was measured in Expt. 3. The interaction between ANFs and pea protein sources (pea protein isolate or raw pea) on digestibility was tested in Expt. 4.

\subsection{Origin of the pea protein sources}

Three varieties of peas were used: spring peas Finale in Expt. 1, winter peas Frijaune in Expt. 2, spring peas
Solara in Expt. 4. Their compositions are reported in Table 1 . The raw pea meals were obtained by grinding in a hammer meal through a $2.5-\mathrm{mm}$ screen.

Two protein concentrates (one from Finale, one from Frijaune) were included in the raw pea diets in order to provide the same amount of native pea protein as in a $60 \%$ pea diet. These concentrates consisted in the light and fine fraction of particles separated from pea meal by an air-classifier set at a cut point of approx. $15 \mu \mathrm{m}$, according to van der Poel et al. (1989).

Three pea protein isolates of different origins and processes were used. Two protein isolates, one from Frijaune and one from Finale, were prepared at INRA research centre at Nantes (France) by acid precipitation at $\mathrm{pH} 4.5$, according to Guéguen (1983). The other protein isolate, produced by ultrafiltration, was obtained from Nutrio in Denmark (P-Pro 2000 pea protein isolate).

Three pea ANF concentrates were produced by ultrafiltration and diafiltration, at INRA-Nantes, from the whey fractions left from the preparation of the pea protein isolates produced by precipitation, which were shown to contain rather high amount of trypsin inhibitors and lectins (Guéguen, 1983). Two ANF concentrates were prepared (one from Finale, one from Frijaune), and mixed together as 1:1 (batch a). A second ANF concentrate was prepared from Frijaune (batch b). The compositions of both batches are reported in Table 1 . The trypsin inhibitor activity was three times higher in batch $b$ than in batch $a$.

Table 1

Chemical composition $(\mathrm{g} / 100 \mathrm{~g}$ raw product) of pea protein sources

\begin{tabular}{|c|c|c|c|c|c|c|c|c|c|c|}
\hline \multirow{2}{*}{$\begin{array}{l}\text { Product } \\
\text { Origin: }\end{array}$} & \multicolumn{3}{|c|}{ Raw pea } & \multicolumn{2}{|c|}{$\mathrm{AC}$ conc. ${ }^{\mathrm{a}}$} & \multicolumn{3}{|c|}{ Pea protein isolate } & \multicolumn{2}{|c|}{ ANF concentrate } \\
\hline & FI & FR & so & FI & FR & Fí & FR & Com. & batch a & batch b \\
\hline DM & 87.1 & 87.1 & nd & 92.0 & 91.4 & 96.5 & 95.9 & 94.4 & nd & nd \\
\hline $\mathrm{CP}^{b}$ & 23.7 & 21.9 & 20.0 & 55.2 & 53.4 & 89.5 & 88.3 & 87.8 & 67 & 70 \\
\hline TIA $^{c}$ & 1.2 & 5.5 & 1.3 & 2.2 & 2.4 & 0.6 & 1.6 & 1.0 & 50 & 163 \\
\hline Lectins $\mathrm{s}^{\mathrm{d}}$ & 3.5 & 3.6 & nd & nd & 2.8 & 1.4 & 1.6 & 6.6 & 102 & 52 \\
\hline
\end{tabular}

FI, FR , SO: Finale, Frijaune and Solara varieties; com: commercial pea protein isolate; batch a: $50 \%$ from FI + 50\% from FR; batch b: $100 \%$ from FR; nd: not determined.

${ }^{a} \mathrm{AC}$ conc.: protein concentrate obtained by air-classification of pea meal.

${ }^{\mathrm{D}} \mathrm{CP}$ : crude protein.

'TIA: trypsin inhibitor activity, in $\mathrm{mg}$ inhibited trypsin/g product.

${ }^{\mathrm{d}}$ Lectins: in $\mathrm{mg} / \mathrm{g}$ product. 
orted in

rinding

tle, one

diets in

protein

isted in

ed from

approx.

).

ins and ne from t INRA ecipitahe other $n$, was 200 pea

sy ultrarom the the pea ch were $n$ inhibconcense from 1. A secFrijaune hes are vity was

:ntrate

batch $b$ nd 70 163 52 $\overline{\mathrm{h} \mathrm{b}: 100 \%}$

\subsection{Diets}

Diet compositions are given in Table 2 (Expts. 1, 2 and 3) and in Table 3 (Expt. 4).

Expt. 1: The objective was to compare raw pea and pea protein isolate from Finale. Three diets were formulated based on either fish meal and casein (control diet C1) or raw pea and air-classified pea protein from spring pea Finale (RP1) or pea protein isolate from spring pea Finale (PP1).
Expt. 2: The objective was to compare raw pea and pea protein isolate from Frijaune. Three diets were formulated based on either fish meal and casein (control $\operatorname{diet} \mathrm{C} 2$ ) or raw pea and air-classified pea protein from winter pea Frijaune (RP2) or pea protein isolate from winter pea Frijaune (PP2).

Expt. 3: The objective was to study the effects of ANF concentrate added to a pea protein isolate diet. To a basal diet based on Finale pea protein isolate (diet PP1) was added $2.9 \%$ ANF concentrate from Finale

Table 2

Composition ( $\mathrm{g} / 100 \mathrm{~g}$ feed) of the diets fed to piglets in Expts. 1,2 and 3

\begin{tabular}{|c|c|c|c|c|c|c|}
\hline Expt. & 1,2 & 1 & 1,3 & 2 & 2 & 3 \\
\hline Diet: & $\mathrm{Cl}, \mathrm{C} 2$ & RP1 & PP1 & RP2 & PP2 & $\mathrm{PPI}^{+}$ \\
\hline Fish meal & 6.9 & - & - & - & - & - \\
\hline Casein & 12.5 & - & - & - & - & - \\
\hline Finale raw pea & - & 25.0 & - & - & - & - \\
\hline Finale air-classified pea protein & - & 18.6 & - & - & - & - \\
\hline Frijaune raw pea & - & - & - & 25.0 & - & - \\
\hline Frijaune air-classified pea protein & - & - & - & 17.8 & - & - \\
\hline INRA pea protein isolate (Frijaune) & - & - & - & - & 17.9 & - \\
\hline INRA pea protein isolate (Finale) & - & - & 18.4 & - & - & 16.4 \\
\hline Pea ANF concentrate (batch a) & - & - & - & - & - & 2.9 \\
\hline Maize starch & 51.8 & 30.0 & 52.2 & 30.7 & 52.7 & 51.3 \\
\hline Cellulose (Arbocell B 800) & 5.0 & 3.0 & 4.8 & 3.0 & 4.8 & 4.8 \\
\hline $\mathrm{CaCO}_{3}$ & 1.2 & 1.5 & 1.5 & 1.5 & 1.5 & 1.5 \\
\hline $\mathrm{CaHPO}_{4}$ & 2.0 & 2.0 & 2.4 & 2.0 & 2.4 & 2.4 \\
\hline $\mathrm{KHCO}_{3}$ & 1.7 & 0.5 & 1.1 & 0.5 & 1.1 & 1.1 \\
\hline DL-methionine & 0.06 & 0.28 & 0.37 & 0.29 & 0.38 & 0.37 \\
\hline L-threonine & - & 0.06 & 0.16 & 0.06 & 0.14 & 0.16 \\
\hline L-tryptophan & - & 0.06 & 0.06 & 0.06 & 0.06 & 0.06 \\
\hline \multicolumn{7}{|l|}{ Chemical composition: analysed (\% DM) } \\
\hline Net energy $(\mathrm{Mcal} / \mathrm{kg} \mathrm{DM})^{a}$ & 0.27 & 0.27 & 0.26 & 0.27 & 0.27 & 0.27 \\
\hline Crude protein & 19.0 & 18.8 & 19.3 & 18.3 & 18.4 & 19.5 \\
\hline Crude fibre ${ }^{a}$ & 5.6 & 5.7 & 5.5 & 5.7 & 5.5 & 5.6 \\
\hline Methionine + cystine & 0.70 & 0.77 & 0.73 & 0.69 & 0.71 & 0.72 \\
\hline Lysine & 1.32 & 1.06 & 1.17 & 1.05 & 1.14 & 1.15 \\
\hline Tryptophan & 0.21 & 0.20 & 0.21 & 0.20 & 0.21 & 0.21 \\
\hline TIA $^{\mathrm{b}}$ & nd & 0.7 & 0.1 & 1.9 & 0.4 & 1.2 \\
\hline Lectins $^{c}$ & nd & 2.3 & 0.4 & 1.9 & 0.5 & 2.7 \\
\hline
\end{tabular}

All diets contained in addition $(\mathrm{g} / 100 \mathrm{~g}$ feed $)$ : dextrose $(15.0)$, sunflower oil (2.0), vitamin/mineral mix $(1.0), \mathrm{NaCl}(0.5), \mathrm{NaHCO},(0.4)$, chromic oxide (0.1).

The vitamin/mineral mix provided ( $\mathrm{mg} / \mathrm{kg}$ feed) : Retinol 2.7, cholecalciferol 0.045 , DL- $\alpha$-Tocopherol 40 , menadione 3 , riboflavine 5 , nicotine acid 30, D-pantothenic acid 15 , choline chloride 120 , cyanocobalamin 0.04 , ascorbic acid $50, \mathrm{CuSO}_{4} \cdot 5 \mathrm{H}_{2} \mathrm{O} 20, \mathrm{ZnSO}_{4} \cdot \mathrm{H}_{2} \mathrm{O}, \mathrm{MnO}_{70}, 200$, $\mathrm{FeSO}_{4} \cdot 7 \mathrm{H}_{2} \mathrm{O} 400, \mathrm{CoSO}_{4} \cdot 7 \mathrm{H}_{2} \mathrm{O} 2.5, \mathrm{Na}_{2} \mathrm{SeO}_{3} \cdot 5 \mathrm{H}_{2} \mathrm{O} 0.2, \mathrm{Kl} 0.5$.

${ }^{a} \mathrm{Calculated}$ values from dutch $\mathrm{CVB}$ tables.

"TIA: trypsin inhibitor activity, in mg inhibited trypsin/g feed.

'Lectins: in mg/g feed. 
Table 3

Composition ( $\mathrm{g} / 100 \mathrm{~g}$ feed) of the diets fed to piglets in Expt. 4

\begin{tabular}{|c|c|c|c|c|c|}
\hline Diets & PP4 & $\mathrm{PP}^{++}$ & RPP4 & $\mathrm{RPP}_{4}^{+}$ & $\mathrm{RPP}^{++}$ \\
\hline Solara raw pea & - & - & 30.0 & 30.0 & 30.0 \\
\hline Commercial PPI & 15.0 & 15.0 & 9.3 & 9.3 & 9.3 \\
\hline INRA PPI ( $50 \% \mathrm{FI}+50 \% \mathrm{FR})$ & 4.0 & 4.0 & 2.4 & 2.4 & 2.4 \\
\hline Pea ANF concentrate (batch b) & - & 0.6 & - & 0.4 & 0.6 \\
\hline Maize starch & 51.4 & 50.8 & 29.2 & 28.6 & 28.8 \\
\hline $\mathrm{KHCO}_{3}$ & 1.1 & 1.1 & 0.6 & 0.6 & 0.6 \\
\hline DL-methionine & 0.38 & 0.38 & 0.35 & 0.35 & 0.35 \\
\hline L-threonine & 0.15 & 0.15 & 0.13 & 0.13 & 0.13 \\
\hline L-tryptophan & 0.07 & 0.07 & 0.07 & 0.07 & 0.07 \\
\hline \multicolumn{6}{|c|}{ Chemical composition: calculated ( $\%$ DM) } \\
\hline Net energy ${ }^{\mathrm{a}}$ (Mcal/kg DM) & 0.27 & 0.26 & 0.26 & 0.26 & 0.26 \\
\hline Crude protein (analysed) & 18.6 & 19.2 & 18.1 & 18.4 & 18.6 \\
\hline Crude fibre & 5.7 & 5.7 & 7.8 & 7.8 & 7.8 \\
\hline Methionine + cystine & 0.75 & 0.74 & 0.78 & 0.78 & 0.78 \\
\hline Lysine & 1.33 & 1.32 & 1.38 & 1.38 & 1.39 \\
\hline Tryptophan & 0.23 & 0.23 & 0.25 & 0.25 & 0.25 \\
\hline $\mathrm{TIA}^{\mathrm{b}}$ & 0.1 & 0.8 & 0.4 & 0.9 & 1.1 \\
\hline Lectins $^{c}$ & 1.5 & 1.9 & 1.9 & 2.5 & 3.4 \\
\hline
\end{tabular}

PPI: pea protein isolate: FI, FR: spring pea Finale and winter pea Frijaune.

All diets contained in addition $(\mathrm{g} / 100 \mathrm{~g}$ feed): dextrose $(15.0)$, sunflower oil (2.0), cellulose-Arbocel B 800 (5.0), vitamin/mineral mix (1.0), $\mathrm{NaCl}(0.5), \mathrm{CaCO}_{3}(1.6), \mathrm{CaHPO}_{4}(2.4), \mathrm{NaHCO}_{3}(0.4)$, chromic oxide (0.1).

"Calculated values from dutch CVB tables.

${ }^{\mathrm{b}}$ Measured TIA: trypsin inhibitor activity, in mg inhibited trypsin/g feed.

cMeasured lectin content: in mg/g feed.

and Frijaune $\left(1: 1\right.$, batch a) (diet $\left.P P 1^{+}\right)$. The ANF concentrate could not be added at a higher level than $2.9 \%$ because of limited quantities available, although the aim was to reach the same trypsin inhibitor activity as in the RP2 diet.

Expt. 4: The objective was to study the effects of ANF concentrate added to a pea protein isolate diet or to a raw pea diet. A first basal diet based on commercial pea protein isolate ( $\mathrm{PP} 4$ diet) was made, to which $0.6 \%$ ANF concentrate from Frijaune (batch b) was added $\left(\mathrm{PP}^{++}\right.$diet). A second basal diet based on Solara raw pea and commercial pea protein isolate (RPP4 diet) was made, to which either $0.4 \%$ or $0.6 \%$ ANF concentrate from Frijaune (batch b) $\left(\mathrm{RPP}^{+}{ }^{+}\right.$diet, $\mathrm{RPP}^{++}{ }^{+}$diet, respectively) was added. Two incorporation levels of ANF concentrate were used in order to balance with the $\mathrm{PP} 4^{++}$diet on TI activity or on the amount of ANF concentrate.

The diets were semi-purified and contained $16 \%$ to $18 \%$ crude protein exclusively from pea proteins except for the control diets. They were balanced in net energy according to CVB tables (1988) and in amino acids using synthetic amino acids. Purified wood cellulose was added to balance the crude fibre content.

Chromic oxide was included at a level of $0.1 \%$ in the diets as a digestibility marker.

The feed was pelleted ( $2.5 \mathrm{~mm}$ diameter) without steam but with addition of $2.5 \%$ water, at an average temperature of 50 to $55^{\circ} \mathrm{C}$.

\subsection{Animal procedures}

Piglets (74 total, five or six animals per treatment) of the crossbred Dutch Landrace $\times$ Yorkshire, obtained from one breeding farm, were allocated to the diets according to live weight and litter. The mean live weights of the animals per treatment group were similar within each experiment.

The piglets were housed individually in metabolism cages designed for ileum cannulated piglets. After 1 week of cage adaptation, at an age of 5 weeks and a live weight of $9 \mathrm{~kg}$, they were surgically fitted with a 
post-valve $T$ caecum cannula at the terminal end of the ileum according to van Leeuwen et al. (1990), and allowed to recover for up to 2 weeks.

After the recovery period, the piglets were adapted to the experimental feed during 10 days in Expts. 1 and 4. In Expts. 2 and 3, 7 days of feed adaptation were allowed as not enough feed could be made for a 10-day adaptation.

Piglets were fed dry pellets at restricted daily energy allowance (2.6 maintenance requirement; ARC, 1981), in two equal meals per day (08:00 and 20:00 h). Water was available ad libitum through a nipple drinker.

Ileal chyme was quantitatively collected in plastic bags, $12 \mathrm{~h}$ per day (08:00-20:00 h) during five consecutive days (van Leeuwen et al., 1990). The bags were changed every hour and weighed before being immediately stored at $-20^{\circ} \mathrm{C}$. At the end of the collection period, the animals weighed 15 to $17 \mathrm{~kg}$.

\subsection{Chemical analysis}

Prior to chemical analysis, the chymes collected per animal were pooled, homogenized, sub-sampled and freeze-dried. Feed and digesta were ground through a 1-mm mesh screen.

Dry matter content was determined by drying the samples to constant weight at $105^{\circ} \mathrm{C}$. Nitrogen was analysed according to AOAC (1980). Trypsin inhibitor activity was determined using the Kakade method as modified by van Oort et al. (1989). Lectin content was measured according to an ELISA technique (Hamer et al., 1989). Chromic oxide content was determined following hydrolysis in a mixture of perchloric and nitric acids and measuring the $\mathrm{Cr}^{6+}$ by flame atomic absorption spectrometry.

\subsection{Calculations and statistical procedures}

汭角ent) obtained he diets ean live e similar rabolism After 1 ks and a d with a
Digestibility coefficients (DC) were calculated from ples. The amounts of collected digesta were corrected using the chromium $(\mathrm{Cr})$ recovery factor.

The following equations were used:

Cr recovery factor $(\%)=\frac{\% \mathrm{CR}_{\mathrm{c}} \times \mathrm{C}}{\% \mathrm{CR}_{\mathrm{f}} \times \mathrm{F}}$, nutrient concentrations in the diets and in digesta sam- where $\% \mathrm{CR}_{\mathrm{c}}=\%$ of $\mathrm{Cr}$ in wet chyme, $\mathrm{C}=$ amount of collected chyme $(\mathrm{g}), \% \mathrm{CR}_{\mathrm{f}}=\%$ of $\mathrm{Cr}$ in the feed, $\mathrm{F}=$ amount of feed intake $(\mathrm{g})$ at 8:00.

$\mathrm{C}_{\text {cor }}=(\mathrm{C} /(\mathrm{Cr}$ recovery factor $)) \times 100$,

where $\mathrm{C}_{\mathrm{cor}}=$ corrected amount of chyme $(\mathrm{g})$

$\mathrm{DC}_{\mathrm{X}}=\frac{\% \mathrm{X}_{\mathrm{f}} \times \mathrm{F}-\% \mathrm{X}_{\mathrm{c}} \times \mathrm{C}_{\mathrm{cor}}}{\% \mathrm{X}_{\mathrm{f}} \times \mathrm{F}}$

where $\% \mathrm{X}_{\mathrm{f}}=\%$ of nutrient $\mathrm{X}$ in feed, $\% \mathrm{X}_{\mathrm{c}}=\%$ of nutrient $X$ in wet chyme.

When calculating the digestibility of $\mathrm{N}$, corrections were made assuming that synthetic amino acids were completely absorbed in the small intestine (Huisman et al., 1986). The $\mathrm{N}$ apparent $\mathrm{DC}$ were calculated for each diet, and corresponded actually to the $\mathrm{N}$ apparent DC of the respective protein sources. The results are given as means with their standard errors.

A one-way analysis of variance was carried out separately for each experiment, using the SPSS/PC software package (Norusis, 1988). The significance of differences between treatment means was tested using the least significance difference test (Snedecor and Cochran, 1980). All statements of significance were based on a probability of less than 0.05 .

Correlation and linear regression calculations were also performed (SPSS package). Two explaining variables were considered: TIA and lectin contents of the diets. Three dependent variables were taken into account: daily weight gain (DWG), $\mathrm{N}$ ileal DC, dry matter ileal DC. For these variables, the means obtained for each treatment group were taken into account, without correction for the experiment.

\section{Results}

Trypsin inhibitor activity (TIA) and lectin content of the diets are given in Table 2 (Expts. 1, 2 and 3) and in Table 3 (Expt. 4). TIA of the diets based on pea protein isolates (PP1, PP2, PP4) were low $(<0.4 \mathrm{mg}$ trypsin inhibited/g feed). TIA of the diets based on raw pea ( $R P 1, R P 2, R P P 4)$ ranked from 0.4 to $1.5 \mathrm{mg}$, depending on the pea variety. TIA of the diets enriched in ANFs $\left(\mathrm{PP}^{+}, \mathrm{PP}^{++}, \mathrm{RPP}^{+}, \mathrm{RPP}^{++}\right)$ranked from 0.8 to $1.2 \mathrm{mg}$. As the commercial pea protein isolate contains more lectins than the INRA pea protein isolate, the PP4 diet had a higher lectin content than the 
Table 4

Feed intake, daily weight gain, chyme production and apparent ileal digestibility of dry matter (DM) and nitrogen (N) in piglets of $10 \mathrm{~kg}$ body weight fed pea diets (Expts. 1 and 2) (mean and standard error between brackets)

\begin{tabular}{|c|c|c|c|c|c|c|}
\hline \multirow[b]{2}{*}{ Diets: } & \multicolumn{3}{|l|}{ Expt. 1} & \multicolumn{3}{|l|}{ Expt. 2} \\
\hline & $\mathrm{C} 1$ & RPl & PP1 & $\mathrm{C} 2$ & RP2 & PP2 \\
\hline Feed intake $(g / d)$ & $\begin{array}{l}527 \\
(19)\end{array}$ & $\begin{array}{l}525 \\
(25)\end{array}$ & $\begin{array}{c}528 \\
(9)\end{array}$ & $\begin{array}{l}560 \\
(34)\end{array}$ & $\begin{array}{l}552 \\
(24)\end{array}$ & $\begin{array}{l}548 \\
(23)\end{array}$ \\
\hline$N$ intake $(g / d)$ & $\begin{array}{l}14.3 \\
(0.5)\end{array}$ & $\begin{array}{l}13.8 \\
(0.7)\end{array}$ & $\begin{array}{l}14.8 \\
(0.3)\end{array}$ & $\begin{array}{l}14.7 \\
(0.9)\end{array}$ & $\begin{array}{l}14.2 \\
(0.6)\end{array}$ & $\begin{array}{l}14.5 \\
(0.6)\end{array}$ \\
\hline Weight gain $(g / d)$ & nd & nd & nd & $\begin{array}{c}323^{\mathrm{a}} \\
(4)\end{array}$ & $\begin{array}{c}239^{\mathrm{b}} \\
(4)\end{array}$ & $\begin{array}{c}(0.0) \\
290^{c} \\
(4)\end{array}$ \\
\hline \multicolumn{7}{|l|}{ Collected ileal chyme } \\
\hline Cr recovery \% & $\begin{array}{l}95.0 \\
(2.4)\end{array}$ & $\begin{array}{c}100.4 \\
(6.2)\end{array}$ & $\begin{array}{l}92.8 \\
(3.3)\end{array}$ & $\begin{array}{l}96.1 \\
(3.7)\end{array}$ & $\begin{array}{c}105.2 \\
(4.8)\end{array}$ & $\begin{array}{l}99.6 \\
(2.3)\end{array}$ \\
\hline $\mathrm{g}$ wet $/ 12 \mathrm{~h}$ & $\begin{array}{l}291^{\mathrm{a}} \\
(35)\end{array}$ & $\begin{array}{l}741^{b} \\
(56)\end{array}$ & $\begin{array}{l}333^{\mathrm{a}} \\
(38)\end{array}$ & $\begin{array}{l}240^{\mathrm{a}} \\
(22)\end{array}$ & $\begin{array}{l}529^{b} \\
(22)\end{array}$ & $\begin{array}{l}298^{\mathrm{a}} \\
(49)\end{array}$ \\
\hline$\% \mathrm{DM}$ & $\begin{array}{l}11.3 \\
(0.9)\end{array}$ & $\begin{array}{c}9.3 \\
(0.8)\end{array}$ & $\begin{array}{l}11.0 \\
(1.0)\end{array}$ & $\begin{array}{l}13.3 \\
(0.9)\end{array}$ & $\begin{array}{l}11.9 \\
(0.5)\end{array}$ & $\begin{array}{l}12.0 \\
(1.1)\end{array}$ \\
\hline $\mathrm{g}$ dry $/ 12 \mathrm{~h}$ & $\begin{array}{l}31.6^{\mathrm{a}} \\
(1.0)\end{array}$ & $\begin{array}{l}66.8^{b} \\
(2.7)\end{array}$ & $\begin{array}{l}34.9^{\mathrm{a}} \\
(1.6)\end{array}$ & $\begin{array}{l}31.3^{\mathrm{a}} \\
(1.5)\end{array}$ & $\begin{array}{l}62.6^{\mathrm{b}} \\
(4.2)\end{array}$ & $\begin{array}{l}33.3^{a} \\
(2.6)\end{array}$ \\
\hline \multicolumn{7}{|c|}{ Apparent ileal digestibility coefficients (\%) } \\
\hline DM & $\begin{array}{l}85.8^{\mathrm{a}} \\
(0.3)\end{array}$ & $\begin{array}{l}73.9^{b} \\
(0.3)\end{array}$ & $\begin{array}{l}84.2^{\mathrm{a}} \\
(0.9)\end{array}$ & $\begin{array}{l}86.3^{a} \\
(0.7)\end{array}$ & $\begin{array}{l}76.8^{b} \\
(0.5)\end{array}$ & $\begin{array}{l}86.9^{\mathrm{a}} \\
(0.4)\end{array}$ \\
\hline $\mathbf{N}$ & $\begin{array}{l}82.4^{\mathrm{a}} \\
(1.0)\end{array}$ & $\begin{array}{l}69.1^{\mathrm{b}} \\
(1.8)\end{array}$ & $\begin{array}{l}83.7^{\mathrm{a}} \\
(1.6)\end{array}$ & $\begin{array}{l}83.1^{a} \\
(1.0)\end{array}$ & $\begin{array}{l}69.5^{b} \\
(1.7)\end{array}$ & $\begin{array}{l}85.4^{a} \\
(0.9)\end{array}$ \\
\hline
\end{tabular}

C1 and C2: control diets; RP1: Finale raw pea diet; RP2: Frijaune raw pea diet; PP1: Finale pea protein isolate diet; PP2: Frijaune pea protein isolate diet.

nd: not determied because the body weight data at the beginning of the adaptation period were not recorded in Expt. 1.

Values within experiment and line with different superscripts differ $(P<0.05)$.

PP1 and PP2 diets ( $1.5 \mathrm{mg}$ vs. $0.5 \mathrm{mg}$, respectively). The raw pea diets and the ANF-concentrate enriched diets contained from 1.9 to $3.4 \mathrm{mg}$ lectins $/ \mathrm{g}$ feed.

The daily weight gains of the piglets, calculated during the feed adaptation + collection period, are reported in Tables 4 and 5 . The average daily weight gain was $276 \mathrm{~g} / \mathrm{d}$ (SE: 5). Compared to the results with pea protein isolates, daily weight gains were significantly lower when the diets were based on raw peas or sometimes when ANF concentrates were added to the diet.

No feed refusals were observed. The daily intakes of feed were similar within the Expts. 1, 2 and 3 (Tables 4 and 5). However, the piglets of Expt. 4 had lower intake of feed ( 475 vs. $544 \mathrm{~g} / \mathrm{d}$ ) and of $\mathrm{N}$ (12.7 vs. $14.7 \mathrm{~g} / \mathrm{d}$ ) than the piglets of Expts. 1, 2 and 3, because they had a lower live weight ( $9 \mathrm{~kg}$ vs. $12 \mathrm{~kg}$ ) (Table 5).
Chromium recovery was high (mean: $98 \%$; SE: 1.0 ) (Tables 4 and 5), indicating adequate cannulation technique for ileal chyme collection under these experimental conditions.

The results concerning the raw pea diets are reported in Table 4. Compared to the diets based on casein + fish meal or pea protein isolate, the raw pea diets gave 2or 3-timés more chyme at the end of the ileum, with DM contents tending to be lower ( $P=0.24$ and 0.42 in Expts. 1 and 2, respectively). The mean apparent ileal digestibility coefficients of $\mathrm{N}$ and $\mathrm{DM}$ were the lowest in raw pea diets: 69 and $75 \%$, respectively. The $\mathrm{N}$ apparent digestibility was not influenced by pea variety (RP1 and RP2).

For the pea protein isolate diets or the control diets, in all experiments (Tables 4 and 5), the total chyme production over 5 days ranged from 230 to 330 g per 
SE: 1.0) ion techexperi-

reported in + fish gave 2Im, with d 0.42 in cent ileal e lowest . The N a variety

rol diets, it chyme 130) $\mathrm{g}$ per

Table 5

Feed intake, daily weight gain, chyme production and apparent ileal digestibility of dry matter (DM) and nitrogen ( $\mathrm{N}$ ) in piglets of $10 \mathrm{~kg}$ fed pea diets (Expts. 3 and 4) (mean and standard error between brackets)

\begin{tabular}{|c|c|c|c|c|c|c|c|}
\hline \multirow[b]{2}{*}{ Diets: } & \multicolumn{2}{|l|}{ Expt. 3} & \multicolumn{5}{|l|}{ Expt. 4} \\
\hline & PP1 & $\mathrm{PP}^{+}{ }^{+}$ & PP4 & $\mathrm{PP}_{4}^{++}$ & RPP4 & $\mathrm{RPP}^{+}$ & $\mathrm{RPP}_{4}^{++}$ \\
\hline Feed intake $(g / d)$ & $\begin{array}{r}558 \\
(8)\end{array}$ & $\begin{array}{l}557 \\
(10)\end{array}$ & $\begin{array}{l}475 \\
(31)\end{array}$ & $\begin{array}{l}473 \\
(22)\end{array}$ & $\begin{array}{l}473 \\
(27)\end{array}$ & $\begin{array}{l}475 \\
(23)\end{array}$ & $\begin{array}{l}480 \\
(21)\end{array}$ \\
\hline $\mathrm{N}$ intake $(\mathrm{g} / \mathrm{d})$ & $\begin{array}{l}15.6 \\
(0.2)\end{array}$ & $\begin{array}{l}15.7 \\
(0.3)\end{array}$ & $\begin{array}{l}12.8 \\
(0.9)\end{array}$ & $\begin{array}{l}13.2 \\
(0.6)\end{array}$ & $\begin{array}{l}12.3 \\
(0.7)\end{array}$ & $\begin{array}{l}12.6 \\
(0.6)\end{array}$ & $\begin{array}{l}12.7 \\
(0.6)\end{array}$ \\
\hline Weight gain ( $g / d$ ) & $277^{a}$ & $229^{\mathrm{b}}$ & $281^{\mathrm{ab}}$ & $289^{\mathrm{ab}}$ & $270^{\mathrm{bc}}$ & $297^{\mathrm{a}}$ & $253^{c}$ \\
\hline
\end{tabular}

Weight gain $(g / d)$

(6)
(3)
(2)

92.2
$(2.1)$
$229^{\mathrm{a}}$
$(21)$
12.3
$(0.8)$
$27.3^{\mathrm{a}}$
$(0.8)$

(4)

(1)

(6)

$\begin{array}{lc}\text { Ileal chyme } & \\ \text { Cr recovery \% } & 94.7 \\ & (3.7) \\ \text { g wet/ } 12 \mathrm{~h} & 278 \\ & (51) \\ \% \mathrm{DM} & 12.3 \\ & (1.6) \\ \mathrm{g} \mathrm{dry} / 12 \mathrm{~h} & 31.2^{\mathrm{a}} \\ & (0.7)\end{array}$

89.5
$(3.0)$
396
$(39)$
9.4
$(0.8)$
$36.2^{\mathrm{b}}$
$(1.1)$

98.7
$(2.2)$
$220^{\mathrm{a}}$
$(11)$
13.4
$(0.7)$
$29.1^{\mathrm{a}}$
$(0.7)$

100.3
$(1.4)$
$372^{\mathrm{b}}$
$(18)$
12.1
$(0.8)$
$44.3^{\mathrm{b}}$
$(1.1)$

102.9

99.1

(3.0)

$398^{\mathrm{b}}$

$\begin{array}{cc}(2.4) & 392^{\mathrm{b}}\end{array}$

(7)

(19)

12.3

12.0

(0.4) $\quad(0.4)$

$46.7^{b} \quad 47.6^{b}$

(1.7) (1.6)

Apparent ileal digestibility coefficients $(\%)$

$\begin{array}{ll}\text { DM } & 86.8^{\mathrm{a}} \\ & (0.4) \\ \mathrm{N} & 86.0^{\mathrm{a}} \\ & (1.0)\end{array}$

$84.1^{\mathrm{a}}$
$(0.3)$
$78.9^{\mathrm{b}}$
$(1.3)$

$86.2^{\mathrm{a}}$
$(0.1)$
$84.7^{\mathrm{a}}$
$(0.7)$

$86.3^{a}$
$(0.1)$
$84.2^{a}$
$(0.6)$

$79.1^{\mathrm{b}}$
$(0.5)$
$80.8^{\mathrm{b}}$
$(1.0)$

\section{$77.9^{\mathrm{c}}$}

$78.5^{\mathrm{bc}}$

(0.3)

$79.4^{\text {be }}$

(0.3)

$77.9^{c}$

(0.5)

PP1: Finale pea protein isolate diet; PP1 ${ }^{+}$; PP1 diet $+2.9 \%$ pea ANF concentrate (batch a); PP4: commercial pea protein isolate diet; PP4 ${ }^{+}$: PP4 diet $+0.6 \%$ pea ANF concentrate (batch $b$ ) $;$ RPP4: $30 \%$ Solara raw pea $+12 \%$ pea protein isolate diet; $R^{2} 4^{+}:$RPP4 diet $+0.4 \%$ pea ANF concentrate (batch b); RPP4 ${ }^{++}$: RPP4 diet $+0.6 \%$ pea ANF concentrate (batch $b$ ).

Values within experiment and line with different superscripts differ $(P<0.05)$.

$12 \mathrm{~h}$, at $11-12 \%$ dry matter content. The digestibility coefficients of the control and pea protein isolate diets (Tables 4 and 5 ) were about $84 \%$ for $\mathrm{N}$ and $86 \%$ for DM. The $\mathrm{N}$ digestibility of the pea protein isolate diets was not affected by pea variety (Table 4 ), or by the process applied to obtain the isolate (precipitation or ultrafiltration, Tables 4 and 5).

The RPP4 diet of Expt. 4, containing 30\% raw pea and $12 \%$ pea protein isolate, gave intermediate results (Table 5).

The addition of $2.9 \%$ pea ANF concentrate (batch a) to pea protein isolate in Expt. 3 ( $\mathrm{PP}^{+}$diet) increased the amounts of dry chyme $(+16 \%)$, and decreased the ileal digestibility coefficients of $\mathrm{N}$ and DM by 7.1 points and 2.7 points, respectively (Table 5).

In Expt. 4 (Table 5), addition of $0.6 \%$ pea ANF concentrate (batch b) to pea protein isolate ( $\mathrm{PP} 4^{++}$ diet) did not affect DM and $\mathrm{N}$ ileal digestibility. However, when $0.4 \%$ or $0.6 \%$ were added to ' $30 \%$ raw pea $+12 \%$ pea protein isolate', the $\mathrm{N}$ and DM apparent ileal digestibility were reduced, significantly in the case of $0.6 \%$ for $\mathrm{N}$ digestibility ( -2.9 units). There was no interaction between the effects of protein source and the effects of addition of $0.6 \%$ ANF concentrate on DM digestibility $(P=0.23)$ and on $\mathrm{N}$ digestibility $(P=0.14)$. The amounts of chyme were not affected by the addition of ANF concentrates.

The highest coefficient of linear correlation calculated between 'TLA or lectin content in the feed' and 'DWG, $\mathrm{DC}_{\mathrm{DM}}$ or $\mathrm{DC}_{\mathrm{N}}$ ' was -0.66 (TIA and $\mathrm{DC}_{\mathrm{N}}$, $n=13$ ). Removing one observation decreased this coefficient to -0.52 , indicating the absence of valuable correlation between these variables in these experiments. The correlation between lectin content and $\mathrm{DC}_{\mathrm{N}}$ was -0.50 . 


\section{Discussion}

The main goal of the experiments was to investigate in piglets the digestibility of raw pea in relation to two of its components - an isolate of its proteins (devoided of carbohydrates and antinutritional factors) and a concentrate of its antinutritional factors. The digestibility coefficients of $\mathrm{N}$ were measured as apparent values. This means that no distinction was made between dietary and non-dietary $\mathrm{N}$ in the chyme. Considering the levels of dietary protein concentration as sufficient and their low variations between diets, the interpretation of the results can be done with the apparent values.

The apparent ileal digestibility coefficients of the raw smooth peas were low, and similar for Frijaune and Finale varieties (Table 4), although the former had a higher trypsin inhibitor activity. Large differences in $\mathrm{N}$ digestibility between varieties of peas (Pisum sativum) fed to pigs have been reported in the literature (Green, 1988; Buraczewska et al., 1989; Gdala et al., 1992). In agreement, Perez and Bourdon (1992) reported two classes of $\mathrm{N}$ apparent faecal digestibility coefficients: $75-88 \%$ for winter pea and $82-89 \%$ for spring pea. Jondreville et al. (1992) found apparent ileal N digestibility values ranging between 61 and $80 \%$ for spring and winter peas, using the end-to-end ileo-rectal anastomosis method. The digestibility coefficients measured in the present study are consistent with the literature data.

The apparent ileal $\mathrm{N}$ digestibility increased by 15 units when the protein source consisted of a pea protein isolate devoided of pea carbohydrates and of pea ANFs, instead of raw pea (Expts. 1 and 2, Table 4).

As a consequence of the preparation process, the proportion of biologically active proteins, called albumins, over the total proteins, was only $10 \%$ in the pea protein isolate instead of $20-30 \%$ in raw pea (Guéguen and Barbot, 1988). If the albumins are poorly digestible, as suggested in a study with radiolabelled pea lectins that partly passed undamaged the small intestine of rats (Aubry and Boucrot, 1986), the proteins of pea protein isolate may therefore be more digestible than the raw pea proteins. However, the commercial pea protein isolate was as digestibile as the other pea protein isolates although it contained more lectins.

The two fractions removed from the pea seeds carbohydrates and ANFs - may be considered as responsible for the differences in digestibility coefficients between raw peas and pea protein isolates.

It has been shown by Darcy et al. (1981) that the type of starch associated with the protein source may influence the apparent ileal digestibility of N. Non starch polysacharides, especially large water-soluble molecules like pectic substances, may also lower the apparent ileal $\mathrm{N}$ digestibility by affecting digestive enzyme activity and increasing pancreatic secretion (Low, 1989; Ikegami et al., 1990). In another study, the addition of purified pea carbohydrates to a pea protein isolate diet did not affect $\mathbf{N}$ apparent ileal digestibility, but it decreased the DM digestibility by 3 units and increased the amounts of ileal chyme produced $(+25$ to $+45 \%, 350$ to $420 \mathrm{~g}$ wet chyme $/ 12 \mathrm{~h}$ ) (Huisman et al., 1990). A lower particle size of the carbohydrate fractions compared to the raw pea meal may have played a role in these effects.

The role of cell walls in the non-accessibility to cytoplasmic content may be an important factor in the limitation of protein and starch digestibility of raw peas (Carré et al., 1991). However, when isolated fractions of peas are studied, this limiting factor is suppressed.

Other dietary constituents that may affect the apparent $\mathrm{N}$ digestibility of the raw pea are ANFs, especially the protease inhibitors. Increased secretion of pancreatic enzymes has been observed in several studies using rats, mice and chickens fed diets including protease inhibitors (Gertler and Nitsan, 1970; Laporte and Trémolières, 1973; Roy and Schneeman, 1981; Temler et al., 1984). If this was the case, higher endogenous $N$ would be present in the chyme, and therefore the apparent $\mathrm{N}$ digestibility would be lower.

The ANFs influence in peas was studied by adding pea ANF concentrates to a diet. The proteins of these concentrates (about $70 \%$ crude protein; Table 1) were mainly albumins, consisting partly of protease inhibitors and lectins, as most of the other proteins, especially the globulins, were precipitated during the isolation process of the pea protein isolates.

Addition of $2.9 \%$ pea ANF concentrate to a pea protein isolate diet reduced the apparent ileal $\mathbf{N}$ digestibility by 7 units (Expt. 3), which was about half the difference in $\mathrm{N}$ digestibility between the pea protein isolate diet and the raw pea diet. However, in Expt. 4, the addition of $0.6 \%$ pea ANF concentrate did not change the digestibility of the pea protein isolate diet. Between both experiments, the TIA levels in the ANF 
ility coeffiolates.

31) that the source may of $\mathrm{N}$. Non ater-soluble o lower the $\mathrm{g}$ digestive c secretion ther study, $\checkmark$ a pea proeal digestiby 3 units e produced 2 h) (Huisthe carboi meal may

lity to cytoin the limif raw peas d fractions ppressed. the apparespecially of pancreidies using g protease te and TréTemler et 'genous $\mathrm{N}$ the appar-

by adding is of these ie 1) were ase inhibiespecially : isolation

to a pea N digestIt half the sa protein n Expt. 4, e did not olate diet. the ANF enriched diets were different ( 1.2 in Expt. 3 vs. 0.8 in Expt. 4). If there is a feed TIA threshold level and if it is higher than 0.8 units, then no effect would be found in Expt. 4. Moreover, the ANF enriched diet in Expt. 3 contained more albumins due to a higher incorporation of ANF concentrate. Assuming that the albumin proteins of the ANF concentrate were totally undigested, the addition of $2.9 \%$ ANF concentrate would decrease the $\mathbf{N}$ digestibility of the pea protein isolate diet by 7 units as measured in Expt. 3. Grant et al. (1986) found in rats a low nutritional value of soybean whey protein fractions soluble at $\mathrm{pH} 4.8$, equivalent to the ANF concentrate used in this study, which could not be correlated directly with the TIA of the fractions.

A low digestibility of the ANF concentrate itself cannot be the only factor explaining the effects of ANF concentrate on digestibility. As the effects of ANF concentrate differs according to diet composition (Expt. 4), the protease inhibitors may play a role, depending on the presence or absence of certain constituents as carbohydrates, on the digestibility of the basal diet. Yen et al. (1977) showed that protease content of pancreas from pigs decreased when TI rich diets were based on raw soybean meal and not when isolated TI were added to heated soybean meal. Likewise, mice fed a $24 \%$ casein diet had the same daily weight gain whether a TI fraction was added to the diet or not (Roy and Schneeman, 1981).

Pea lectins also could affect the digestibility. Their role could be linked to their own low digestibility (Aubry and Boucrot, 1986). On the other hand, they could be toxic if they bind to the carbohydrate moiety of the glycoproteins of the small intestinal brush border membrane (Kik, 1991). Concerning pea lectins, conflicting views are reported in literature. Purified pea lectins did not affect piglets and rats in any way (Grant et al., 1983; Bertrand et al. 1988; Aubry and Boucrot, 1986). On the other hand, Jindal et al. (1982) observed that they damaged the gutwall of rats.

\section{Conclusion}

Four experiments using piglets fed diets containing pea proteins showed lower apparent ileal $\mathrm{N}$ digestibility coefficients when the proteins consisted of raw peas rather than pea protein isolates. The pea ANFs were shown to be partly involved in this difference. It should be determined whether the protein composition (albumins) or the protein properties (TLA, lectins) of the ANF concentrate were responsible. The ANF effects differed according to diet composition. Experiments on pancreatic enzymes should give indications on ANF mode of action for different diets. The results also showed that isolation technique is valuable to study the relationship between biochemistry and nutrition but do not take into account the microstructure of the feed. In that respect, the physical role of cell walls and the importance of the simultaneous presence of constituents would be interesting studies.

\section{Acknowledgements}

The authors wish to thank S. Bérot (INRA, Nantes, France) for the preparation of the isolates and concentrates from peas, P. van Leeuwen, D.J. van Kleef, A. Hoek and T. Zandstra for surgery and technical assistance during the experiment, R. Coolen and A.M. van den Driessche for chemical analysis, and J. Wiebenga for statistical analysis of data.

\section{References}

Agricultural Research Council, 1981. The Nutrient Requirements of Farm Livestock. No. 3. Pigs. Technical Review and Summaries. A.R.C., London.

Association of Official Analytical Chemists, 1980. Official Methods of Analysis, 13th edn. A.O.A.C., Washington, DC.

Aubry, M. and Boucrot, P., 1986. Etude comparée de la digestion des viciline, légumine et lectine radiomarquées de Pisum sativum chez le rat. Ann. Nutr. Metab., 30: 175-182.

Bengala Freire, J., Peiniau, J., Lebreton, Y. and Aumaitre, A., 1988. Determination of ileal digestibility by shunt technique in the early-weaned pig: methodological aspects and utilisation of starch-rich diets. Livest. Prod. Sci., 20: 233-247.

Bengala Freire, J., Hulin, J.C., Peiniau, J. and Aumaitre, A., 1989. Effet de la cuisson-extrusion du pois de printemps sur la digestibilité des aliments de sevrage précoce du porcelet et conséquences sur les performances jusqu'à l'abartage. Journ. Rech. Porcine Fr., 21: 75-82.

Bertrand, G., Sève, B., Gallant, D.J. and Tomé, R., 1988. Absence d'effets antinutritionnels des lectines de pois, sous forme native ou purifiée chez le: porcelet. Comparaison avec les lectines natives de soja. Sci. Alim., 8: 187-212.

Buraczewska, L., Gdala, J. and Grala, W., 1989. Ileal digestibility of protein in pigs fed diets with peas of variable content of protein and tannins. In: J. Huisman, A.F.B. van der Poel and I.E. Liener (Eds.), Recent Advances of Research in Antinutritional Factors 
in Legume Seeds. Pudoc, Wageningen, The Netherlands, pp. 181-184.

Carré, B., Beaufils, E. and Melcion, J.P., 1991. Evaluation of protein and starch digestibility and energy value of pelleted and unpelleted pea seeds from winter or spring cultivar in adult and young chickens. J. Agric. Food Chem., 39: 468-472.

Colonna, P. and Mercier, C., 1979. Revue bibliographıque: les amidons de légumineuses, aspect, composition, structure et propriétés physicochimiques. Lebensm.-Wiss. u.-Technol., 12: 1 12.

Colonna, P., Buleon, A. and Doublier, J.L., 1992. Structural features of smooth and wrinkled pea starches. Proceedings of the lst European Conference on Legume Seeds. 1-3 June 1992. Angers, pp. 401-402.

Cristofaro, E., Mottu, F. and Wuhrmann, J.J., 1974. Involvement of the raffinose family of oligosaccharides in flatulence. In: H.L. Sipple and K.W. McNutt (Eds.), Sugars in Nutrition. Academic Press, New York, pp. 313-336.

CVB, 1988. Veevoedertabel: Gegevens over voederwaarde, verteerbaarheid en samenstelling. Centraal Veevoederbureau in Nederland, Lelystad, The Netherlands.

Darcy, B., Laplace, J.P. and Villiers, P.A., 1981. Digestion dans l'intestin grêle chez le porc. 4 . Cinétique de passage des digesta au niveau de la jonction iléo-caeco-colique et bilans de la digestion selon la nature de l'amidon et la source de protéines alimentaires. Ann. Zootech., 30: 31-62.

Gatel, F., Fekete, J. and Grosjean, F., 1989. Introduction de $30 \%$ de pois de printemps dans les régimes pour porcelets sevrés: influence de la teneur en acides aminés soufrés des régimes. Journ. Rech. Porcine Fr., 21: 83-88.

Gdala, J., Buraczewska, L. and Grala, W., 1992. The chemical composition of different types and varieties of pea and the digestion of their protein in pigs. J. Anim. Feed Sci., 1: 71-79.

Gertler, A. and Nitsan, Z., 1970. The effect of trypsin inhibitors on pancreatopeptidase E, trypsin and chymotrypsin and amylase an the pancreas and intestinal tract of chicks receiving raw and heated soya-bean diets. Br. J. Nutr., 24: 893-904.

Grant, G., More, L.J., McKenzie, N.H., Stewart, J.C. and Pusztai, A., 1983. A survey of the nutritional and haemagglutination properties of legume seeds generally available in the UK. Br. J. Nutr., 50: 207-214.

Grant, G., McKenzie, N.H., Watt, W.B., Stewart, J.C., Dorward, P.M. and Pusztai, A., 1986. Nutritional evaluation of soya beans (Glycine max) : nitrogen balance and fractionation studies. J. Sci. Food Agric., 37: 1001-1010.

Green, S., 1988. A note on amino acid digestibility measured in pigs with pre- or post-valve ileo-rectal anastomoses, fed soya-bean, pea and meat meals. Anim. Prod., 47: 317-320.

Griffiths, D.W., 1984. The trypsin and chymotrypsin inhibitor activities of various pea (Pisum spp.) and field bean (Vicia faba) cultivars. J. Sci. Food Agric., 35: 481-486.

Grosjean, F., Bourdon, D., Kiener, T., Castaing, J. and Gatel, F., 1991. Valeur alimentaire pour les porcs des pois français et importés. Journ. Rech. Porcine Fr., 23: 53-60.

Guéguen, J., 1983. Legume seed protein extraction, processing, and end product characteristics. Qualit. Plant.: Plant. Food. Hum. Nutr., 32: 267-303.
Guéguen, J. and Barbot, J., 1988. Quantitative and qualitative variability of pea (Pisum sativum L.) protein composition. J. Sci. Food Agric., 42: 209-224.

Hamer, R.J., Koninkx, J., van Oort, M.G., Mouwen, J. and Huisman, J., 1989. New developments in lectin analysis. In: J. Huisman, A.F.B. van der Poel and I.E. Liener (Eds.), Recent Advances of Research in Antinutritional Factors in Legume Seeds. Pudoc Wageningen, The Netherlands, pp. 30-33.

Huisman, J., De Vries, P.H., van Weerden, E.J. and Bertram, H.L. 1986. The availability of synthetic methionine in pigs. J. Anim. Nutr. Phys., 55: 267-272.

Huisman, J., Le Guen, M.P., Bérot, S. and van Weerden, E.J., 1990. Digestive response of piglets to isolated fractions from peas. 2. Investigation into factors responsible for negative effects on performance of piglets fed high levels of peas: carbohydrates and antinutritional factors. PhD Thesis, Agricultural University, Wageningen, The Netherlands, pp. 99-112.

Ikegami, S., Tsuchihashi, F., Harada, H., Tsuchihashi, N., Nishide, E, and Innami, S., 1990. Effect of viscous indigestible polysaccharides on pancreatic-biliary secretion and digestive organs in rats. J. Nutr., 120: 353-360.

Jindal, S., Soni, G.L. and Singh, R., 1982. Effect of feeding of lectins from lentils and peas on the intestinal and hepatic enzymes of albino rats. J. Plant Foods, 4: 95-103.

Jondreville, C., Grosjean, F., Buron, G., Peyronnet, C. and Beneytout, J.L., 1992. Comparison of four pea varieties in pig feeding through digestibility and growth performance results. J. Anim. Physiol. Anim. Nutr., 68: 113-122.

Kik, M.J.L., 1991. Effects of lectins in legume seeds on the structure and function of the small intestinal mucosa: in vivo and in vitro studies. PhD Thesis, University of Utrecht, The Netherlands, 132 pp.

Laporte, J.C. and Trémolières, J., 1973. Action de la trypsine et des inhibiteurs trypsiques sur la sécrétion pancréatique. Nutr. Metab.,

Leterme, P., Beckers, Y. and Thewis, A., 1990. Trypsin inhibitors in peas: varietal effect and influence on digestibility of crude protein by growing pigs. Anim. Feed Sci. Technol., 29: 45-55.

Longstaff, M. and McNab, J.M., 1987. Digestion of starch and fibre carbohydrates in peas by adult cockerels. Br. Poult. Sci., 28:261285.

Low, A.G., 1989. Secretory response of the pig gut to non-starch polysaccharides. Anim. Feed Sci. Technol., 23: 55-65.

Meehan, E.J., McDuffie, J., Einspahr, H., Bugg, C.E. and Suddath, F.L., 1982. The crystal structure of pea lectin at $6-\AA$ resolution. J. Biol. Chem., 257: 13278-13282.

Quemener, B. and Mercier, C., 1980. Dosage rapide des glucides éthanolosolubles des graines de légumineuses par chromatographie liquide sous haute pression. Lebensm.-Wiss. u.-Technol., 13: 7-12.

Norusis, M.J., 1988. Base manual for the IBM PC/XT/AT and PS/ 2. SPSS Inc., Chicago, IL.

Perez, J.M. and Bourdon, D., 1992. Energy and protein value of peas for pigs: synthesis of French results. Proceedings of the 1st European Conference on Legume Seeds. 1-3 June 1992. Angers, pp.
$489-490$. 
Roy, D.M. and Schneeman, B.O., 1981. Effect of soy protein. casein and trypsin inhibitor on cholesterol, bile acids and pancreatic enzymes in mice. J. Nutr., 111: 878-885.

Saini, H.S., 1989. Legume seed oligosaccharides. In: J. Huisman, A.F.B. van der Poel and I.E. Liener (Eds.), Recent Advances of Research in Antinutritional Factors in Legume Seeds. Pudoc, Wageningen, The Netherlands, pp. 329-341.

Snedecor, G.W. and Cochran, W.G., 1980. Statistical Methods. 7th edn. The Iowa State University Press. Ames, IA

Temler, R.S., Dormond, C.A., Simon, E. and Morel, B., 1984. The effect of feeding soybean trypsin inhibitor and repeated injections of cholecystokinin on rat pancreas. J. Nutr., 114: 1083-1091.

Valdebouze, P., Bergeron, P., Gaborit, T. and Delort-Laval, J., 1980 Content and distribution of trypsin inhibitors and haemagglutinins in some legume seeds. Can. J. Plant Sci., 60: 695-701.

Van Leeuwen, P., Van Kleef, D.J., Van Kempen, G.J.M., Huisman, J. and Verstegen, M.W.A., 1990. The post valve T-caecum can- nulation technique in pigs applicated to determine the digestibility of amino acid in maize, groundnut and sunflower meal. J. Anim. Physiol. a. Anim. Nutr., 65: 183-193.

Van Oort, M.G., Hamer, R.J. and Slager, E.A., 1989. The trypsin inhibitor assay; improvement of an existing method. In: J. Huisman, A.F.B. van der Poel and I.E. Liener (Eds.), Recent Advances of Research in Antinutritional Factors in Legume Seeds. Pudoc, Wageningen, The Netherlands, pp. 110-113.

Van der Poel, A.F.B., Aarts, H.L.M. and Stolp, W., 1989. Milling and air-classification of two different types of peas: effect on the distribution of antinutritional factors. Neth. J. Agric. Sci., 37; 273-278.

Yen, J.T., Jensen, A.H. and Simon, J., 1977. Effect of dietary raw soybean and soybean trypsin inhibitor on trypsin and chymotrypsin activities in the pancreas and in small intestinal juice of growing swine. J. Nutr., 107: 156-165.

\section{Résumé}

Le Guen, M.P., Huisman, J., Guéguen, J., Beelen, G. et Verstegen, M.W.A., 1995. Effets d'un concentré de facteurs antinutritionnels de pols sur la digestibilité des protéines de pols chez le porcelet. Livest. Prod. Sci., 44: 157-167.

Quatre expériences ont été réalisées pour étudier la digestibilité iléale apparente du pois (Pisum sativum) et de deux de ses constituants - un isolat de ses protéines et un concentré de ses facteurs antinutritionnels des protéines (ANF). Trois variétés de pois étaient utilisées: les varietés de printemps Finale et Solara, et la variété d'hiver Frijaune. Les isolats de protéines de pois, débarrassés des glucides du pois et caractérisés par de faibles activités antitrypsiques, étaient produits à partir de Finale et de Frijaune. Deux concentrés d'ANF étaient utilisés, l'un provenant de Finale et de Frijaune ( $1: 1$ ) (lot a), l'autre de Frijaune (lot b). L'activité antitrypsique était trois fois plus forte dans le lot b que dans le lot a. Onze régimes semi-synthétiques renfermant l'isolat de protéines de pois, les concentrés d'ANF de pois ou le pois ou le pois étaient distribués à des porcelets ( $10-15 \mathrm{~kg}$ de poids vii) porteurs d'une canule en T placée après la valvule du caccum. Lorseque les régimes étaient constitués de pois, les coefficients de digestibilité iléale apparente de N étaient de $69,1 \%$ (Finale) et $69.5 \%$ (Frijaune). Dans le cas des régimes à base d'isolat de protéines de pols, Ils étaient de $83,7 \%$ (Finale) et $85,4 \%$ (Frijaune). L'incorporation de 2,9\% de concentré d'ANF (lot a) réduisait le coeffient de digestibilité de l'azoie du régime à base d'isolat de protéines de pois Finale de 83,7 à $79 \%$. L'addition de $0.6 \%$ de l'autre concentré d'ANF (lot b) diminuait le coefficient de digestibilité de l'azote lorsque le régime était à base de pois Solara ( -3 unités), et non lorsqu'il était à base d'isolat de protéines de pois.

\section{Kurzfassung}

Le Guen, M.P., Huisman, J., Guéguen, J., Beelen, G. und Verstegen, M.W.A., 1995. Wirkung eines Konzentrats der antinutritiven Faktoren aus Erbsen auf die Verdaulichkeit von Erbsenprotein bei Ferkeln. Livest.. Prod. Sci., 44: 157-167.

Vier Versuche wurden vorgesehen zur Bestimmung der scheinbaren ilealen Verdaulichkeit roher Erbsen (Pisum sativum) und von zwei Bestandteilen derselben - ein Protein-Isolat und ein Konzentrat der Protein-ähnlichen antinutritiven Faktoren (ANF). Drei Erbsensorten wurden verwendet: Die Sommersorten Finale und Solara und die Wintersorte Frijaune. Diese Proteinisolate, die von Kohlenhydraten getrennt waren und sich durch niedrige Aktivitäten der Trypsininhibitoren auszeichneten, wurden von Finale und von Frijaune hergestellt. Zwei Konzentrate der ANF wurden verwendet; eins von Finale und Frijaune (1:1) (Charge a) und eins von Frijaune (Charge b). Die Aktivität des Tripsinhibitors war dreimal höher in Charge $b$ als in Charge a. Elf semisynthetische Futtermischungen, die das Erbsenproteinisolat, die Erbsen-ANF-Konzentrate oder rohe Erbsen enthielten, wurden an Ferkel gefüttert (10-15 kg Lebensmasse), welche mit post-valvulären TKanülen im Caecum versehen waren. Für die Mischungen mit rohen Erbsen betrug die ileale Verdaulichkeit des N 69,1\% (Finale) und 69,5\% (Frijaune). Für Mischungen mit Erbsenproteinisolat betrugen sie 83,7\% (Finale) und 85,4\% (Frijaune). Zulagen von 2,9\% ANFKonzentrat (Charge a) reduzierten die N-Verdaulichkeit in der Mischung mit Finale Erbsenproteinisolat von 83,7\% auf 79\%. Die Zulage von 0,6\% des anderen ANF-Konzentrates (Charge b) reduzierte die N-Verdaulichkeit, wenn die Mischung rohe Solare Erbsen enthielt (3 Einheiten) aber nicht bei Verwendung des Proteinisolates. 